\title{
KINERJA KEUANGAN USAHA MIKRO DAN KECIL
}

\author{
Winbaktianur ${ }^{1}$, Liesma Maywarni Siregar ${ }^{2}$ \\ ${ }^{1}$ UIN Imam Bonjol \\ ${ }^{2}$ Universitas Muhammadiyah Sumatera Barat \\ liesmamsiregar@gmail.com
}

\begin{abstract}
ABSTRAK
UMK merupakan salah satu bentuk usaha yang dasar pendiriannya berasal dari individu atau sekelompok orang. Dalam prakteknya sudah banyak dukungan yang diberikan bagi unit usaha skala ini walaupun hasil produksi atau jasanya masih berskala kecil dan dalam bersaing dengan usaha menengah dan besar belum mampu bersaing. Perencanaan dan pengendalian perlu dilakukan yang mana tujuan utamanya adalah untuk mencapai tujuan. Perencanaan dibuat untuk mempermudah dilakukannya penilaian atau evaluasi terhadap aktivitas usaha. Penilaian kinerja penting dilakukan untuk melihat sejauh mana usaha yang dijalankan telah mencapai tujuan, secara finansial mengukur seberapa besar profit yang diperoleh dalam suatu periode. Tujuan tulisan ini adalah membahas mengenai pentingnya dilakukan penilaian kinerja wirausaha skala usaha mikro dan kecil. Metode dalam tulisan adalah riset pustaka. Dalam pembahasannya akan diuraikan mengenai apa itu penilaian kinerja, faktor-faktor penilaian kinerja dan indikatornya serta diakhiri dengan manfaat dilakukannya penilaian kinerja keuangan.
\end{abstract}

Kata kunci: Usaha Mikro dan Kecil, penilaian kinerja, wirausaha.

\begin{abstract}
SMEs is one of the basic forms of business stance developed from an individual or a group of people. In practice there has been a lot of support given to this business category even though the products or services is still small competing with medium and large businesses. Planning and control needs to be done which is the goal the main thing is to achieve the goal. Planning is made for facilitate the assessment or evaluation of business activities. Performance appraisal is important to see to what extent the business that is carried out has reached the goal, financial performance how much profit is obtained in a period. The purpose of this research is to discuss the importance of conducting a performance appraisal micro and small scale entrepreneurship. The method of this paper is library research. In discussion, it will describe what assessment is performance, performance appraisal factors and indicators as well as terminated with the benefit of doing a financial performance appraisal.
\end{abstract}

Keywords: Micro and Small Enterprises, performance appraisal, entrepreneurship

\section{PENDAHULUAN}

Badan Pusat Statistik (BPS) Indonesia merilis data mengenai dunia usaha di Indonesia. Jiak dilihat, data BPS tersebut masih dominannya dikuasai oleh skala Usaha Mikro Kecil (UMK) dengan jumlah mencapai 26 juta usaha atau dengan persentase 98,68 persen dan merupakan bukan sektor pertanian. Bahkan UMK mampu menyerap 59 juta atau 75,33 persen tenaga kerja. Apabila diperhatikan maka skala UMK memberikan peluang pekerjaan dalam jumlah yang sangat besar serta mempunyai jumlah usaha yang tidak sedikit karena dominasinya dan memberikan sumbangan besar terhadap perekonomian negara ini (BPS, 2018).

Entrepreneur (wirausaha) maupun entrepreneurship (kewirausahaan) telah menarik banyak minat peneliti diseluruh dunia serta di Indonesia. Menurut Undang-Undang (UU No. 20 Tahun 2008), tentang UMKM disebutkan: "usaha ekonomi produktif yang berdiri sendiri, yang dilakukan oleh orang perorangan atau badan usaha yang bukan merupakan anak perusahaan atau 
bukan cabang perusahaan yang dimiliki, dikuasai, atau menjadi bagian baik langsung maupun tidak langsung dari usaha menengah atau usaha besar yang memenuhi kriteria Usaha Kecil sebagai mana dimaksud dalam undang-undang ini".

UMK dalam aktivitasnya memanfatkan berbagai potensi yang terdapat dalam suatu daerah yang belum dimanfaat untuk mendatangkan nilai ekonomi. Jika hal ini dilakukan dengan maksimal maka dapat berkontribusi kepada pendapatan daerah dan secara tidak langsung juga menambah pendapatan negara. Saat krisis dan pasca krisis sekitar dua dekade lalu, UMK memberikan kontribusi yang tidak sedikit terhadap bangsa ini. Maka tidak berlebihan seandainya pemerintah memberikan perhatian pada pengembangan sektor swasta dan salah satunya fokus pada UMK. Terkadang usaha skala ini mendapat porsi yang kecil dikarenakan hasil produksi atau jasanya dalam skala yang kecil dan kalah bersaing dengan skala usaha menengah dan skala usaha besar.

Seorang wirausaha UMK perlu melakukan perencanaan dan juga pengendalian demi tercapainya tujuan usaha, salah satunya adalah meraih keuntungan. Karena penting bagi wirausaha untuk menyusun rencana serta upaya pengendalian terhadap semua aktivitas bisnis. Salah atu tujuan disusunya rencana adalah untuk mempermudah dilakukannya penilaian atau evaluasi terhadap aktivitas atau kinerja usaha. Penilaian kinerja penting dilakukan untuk melihat sejauhmana bisnis yang dijalankan telah mencapai tujuan, dimana secara finansial mengukur seberapa besar profit yang diperoleh dalam suatu periode.

Berbagai krisis yang pernah melanda Indonesia telah menarik perhatian parah peneliti untuk melihat bagaimana kekuatan yang dimiliki oleh UMKM. Terbukti dari banyaknya penelitian-penelitian sehubungan dengan UMKM ini yangtelah dipublikasikan. Selain itu juga terlihat bahwa pemerintah dengan kebijakannya dalam upaya membantu peningkatan daya saing kinerja UMKM terlihat cukup besar. Misalnya memberikan berbagai pelayanan dan kemudahan bagi UMKM, upaya untuk restrukturisasi UMKM, membuka akses yang luas terhadap perbankan serta berbagai program pembinaan sumberdaya manusia UMKM. Namun berbagai program yang diluncurkan pemerintah tidak dapat berjalan sendiri tanpa mendapat perhatian yang lebih serius dari berbagai kalangan terutama pelaku usaha UMKM itu sendiri. Para pengusaha UMKM dalam menjalankan aktifitas bisnisnya juga menghadapi berbagai kendala, salah satunya adalah pengelolaan keuangan. Dampak dalam jangka pendek memang tidak langsung terlihat jelas, namun jika dibiarkan secara berterusan maka dapat mengakibatkan gagalnya dalam mengembangkan usaha karena tidak menggunakan metode akuntansi yang efektif, akibat terburuknya adalah usaha mengalami kebangkrutan. Maka akuntansi dianggap sebagai salah satu kunci indikator kinerja usaha.

Catatan-catatan akuntansi yang dilakukan sangat berguna untuk membuat keputusan sehingga pada akhirnya dapat meningkatkan pengelolaan bisnis UMKM. Tersedianya informasiinformasi akuntansi tersebut membantu pengusaha UMKM untuk melakukan identifikasi dan membuat prediksi terhadap berbagai masalah yang mungkin terjadi, dan dapat melakukan tindakan perbaikan tepat waktu sesuai dengan kebutuhan. Sekurang-kurangnya pengusaha UMKM dapat menghitung untung rugi bisnisnya atau dapat memahami makna untung atau rugi atas bisnisnya. Adanya pengelolaan keuangan yang baik serta transparan akan memberikan dampak yang sangat positif kepada stakeholder UMKM, seperti kreditor, pemasok, karyawan dan manajemen usaha.

Perlu diingat bahwa aspek kinerja perusahaan merupakan hal yang penting selain memperoleh laba. Karena itu yang perlu dilakukan oleh pelaku usaha UMKM adalah tidak hanya bagaiman usaha untuk memperoleh laba, namun disamping itu hal yang penting lagi yaitu bagaimana upaya untuk meningkatkan kinerja perusahaan. Kinerja usaha berhubungan dengan bagaimana UMKM mengelola sumber daya yang dimiliki dalam menghasilkan keuntungan yang akan meningkatkan kemakmuran usahanya. Jadi kinerja tidak hanya sekedar memperoleh laba yang besar akan tetapi juga berhubungan dengan efektifnya UMKM dalam mengelola bisnisnya tersebut. Salah satu di antaranya kinerja UMKM adalah kinerja keuangan. Bertolak dari uraian di 
atas, dapat dirumuskan bahwa tujuan tulisan ini adalah membahas mengenai pentingnya dilakukan kinerja keuangan wirausaha skala UMK.

\section{KAJIAN PUSTAKA Kinerja Wirausaha}

Istilah success atau business success lebih banyak dijumpai dalam berbagai penelitian yang berkaitan dengan kewirausahaan jika dibandingkan dengan penggunaan istilah entrepreneurial performance. Pengertian sukses (success) dekat dengan istilah performansi (performance) atau pertumbuhan usaha (growth) atau kinerja. Masing-masing peneliti menggunakan istilah yang tidak sama, dan memberikan gambaran bahwa istilah entrepreneurial performance dapat diganti dengan istilah lain yang mempunyai makna yang sama (Reijonen dan Komppula, 2007)

Menurut Welter (2012), karena tidak seragamnya penggunaan istilah entrepreneurial performance, maka memberikan dampak terhadap perumusan definisi atau pengertiannya dan dapat menimbulkan pemahaman yang tidak sama pada setiap orang. Keberhasilan usaha sulit untuk didefinisikan sehingga tidak mempunyai definisi tunggal dalam memahami wirausaha. Lebih lanjut, Paige \& Littrell, (2002) mendefinisikan kesuksesan sebagai bentuk kriteria intrinsik yang di dalam terdapat kebebasan dan kemandirian, masa depan individu yang dikendalikan, serta mampu menjadi pemimpin untuk dirinya sendiri; sedangkan hasil ekstrinsik berupa peningkatan pengembalian keuangan, penghasilan pribadi, dan kekayaannya.

Masuo dkk., (2001) berpendapat bahwa keberhasilan bisnis umumnya didefinisikan dalam bentuk ukuran ekonomi atau keuangan yang terdiri dari pengembalian aset, penjualan, profit, karyawan, dan keberlangsungan hidup usaha; sedangkan untuk non-keuangan, di antaranya kepuasan pelanggan, pengembangan dan pencapaian diri pribadi.

Sebagian wirausaha mengukur keberhasilannya ketika mereka dapat melihat bahwa sesuatu itu merupakan sumber daya yang mempunyai nilai ekonomi. Dimana wirausaha beranggapan telah menghasilkan pendapatan dan telah berkontribusi untuk keluarganya, serta merasa telah telah menggapai beberapa ukuran keberhasilan (Dhaliwal, 2000).

Bagi Reijonen dan Komppula (2007), sebagai kemampuan individu atau obyek untuk menghasilkan sesuatu pada suatu dimensi yang ditetapkan secara a priori, yang berhubungan dengan tujuan. Kesuksesan merupakan bentuk kesetaraan dengan operasi atas usaha yang berkelanjutan, dan kegagalan merupakan kebalikannya, yaitu mundur dari usaha, dan sukses dianggap sebagai: tercapainya tujuan seseorang.

Menurut Robbins (2001), kinerja merupakan fungsi interaksi antara kecakapan atau ability (A), motivasi atau motivation (M) dan peluang atau opportunity (O). Jika dicantumkan dalam sebuah formula adalah sebagai berikut; kinerja $=\mathrm{f}(\mathrm{AxMxO})$. Dimana kinerja merupakan fungsi dari kecakapan, motivasi, dan peluang. Otley (1999) berpeendapat bahwa kinerja merujuk kepada sesuatu yang berhubungan dengan aktivitas melakukan pekerjaan yang merupakan hasil yang dicapai pekerjaan tersebut (Otley, 1999).

Definisi kinerja juga dikemukakan oleh Laitinen (2002), sebagai suatu adalah kemampuan obyek untuk menghasilkan sesuatu dalam dimensi yang ditetapkan secara a priori, dalam kaitannya dengan target. Selain itu juga menggambarkan tata kelola yang tepat dan mengukur kinerja dianggap sebagai mekanisme yang paling tepat dari sudut pandang organisasi dalam meningkatkan keuntungan terhadap penerapan strategi yang berhasil.

Indikator kinerja yang umum digunakan adalah berupa jumlah penjualannya dan kinerja sektor keuangan yang kerap digunakan adalah sumbangan laba bruto masing-masing pekerja sebagai pengukuran kinerja (O’Regan, Sims, \& Ghobadian, 2005). Menurut Sahabuddin (2015), kinerja atau prestasi usaha adalah merupakan hasil yang diperoleh perusahaan, baik secara kualitas maupun kuantitas dalam periode tertentu.

Kinerja wirausaha didefinisikan dalam hubungannya dengan keluaran (output) dari wirausahawan. Hal ini mengacu kepada tingkat pencapaian wirausahawan dalam menjalankan 
bisnisnya. Pencapaian juga dapat diukur antara lain dengan melihat jumlah karyawan, tingkat laba dan volume penjualan. Hal ini merujuk pada hasil dari usaha yang dilakukan oleh seorang pengusaha ke dalam bisnis yang dipengaruhi oleh berbagai faktor (Nneka, 2015). Islam dkk., (2011) berpendapat bahwa keberhasilan usaha dapat diukur berdasarkan tingkat survive, laba yang diperoleh, hasil dari investasi, hasil penjualan produk, jumlah karyawan, merasa bahagia, perolehan nama baik dan lain-lainnya.

Dari berbagai pendapat di atas menggambarkan bahwa ada dua sisi dari performance wirausaha yang harus diperjelas. Pertama, istilah performansi wirausaha sendiri tidak semata-mata diartikan sebagai performance seperti yang dimaksudkan oleh peneliti-peneliti yang mempublikasikan hasil penelitiannya dalam sejumlah jurnal, meskipun istilah performansi bisa diterjemahkan dengan kinerja. Istilah ini dalam berbagai penelitian disebut secara bergantian dengan istilah lain, misalnya seperti success atau growth, dan sampai saat ini tidak ada yang memperdebatkannya. Tergambar bahwa tidak ada kesepakatan untuk menyebut istilah performansi, kinerja, kesuksesan atau pertumbuhan. Karena itu, istilah-istilah di atas dapat digunakan bergantian untuk menyatakan maksud yang sama (Winbaktianur dkk, 2020). Akan tetapi dalam konteks penelitian ini, istilah yang digunakan adalah kinerja wirausaha, yang lebih khususnya lagi adalah kinerja keuangan yang akan dibahas lebih lanjut berikut ini.

Lebih lanjut, menurut (Winbaktianur dkk, 2020), yang kedua, cukup sulit menemukan arti atau definisi kinerja wirausaha karena memiliki masalah yang sama dengan penyebutannya karena tidak ada kesepakatan dan sifatnya cenderung persepsi individu. Sebagaimana halnya tergambar pada uraian di atas bahwa adanya perbedaan dalam menyebutkan arti atau definisi kinerja usaha.

Menurut Venkatraman \& Ramanujam (1986) membagi kinerja perusahaan ke dalam tiga bagian yaitu; kinerja keuangan, kinerja bisnis, dan kinerja keorganisasian. Untuk kinerja keuangan diukur berdasarkan penerimaan atas aset (return on asset), penerimaan atas penjualan (return on sales), dan return on equity. Sedangkan Umar (2006) berpendapat bahwa informasi kinerja adalah salah satu perangkat bagi pihak manajemen untuk menilai dan mencermati perkembangan yang diraih selama ini atau dalam jangka waktu tertentu.

Lebih lanjut Umar (2006) menyatakan bahwa kinerja adalah alat untuk mengukur indikator keberhasilan perusahaan dalam upaya mencapai tujuan perusahaan. Berisikan gambaran mengenai tingkat keberhasilan pelaksanaan suatu aktivitas atau program untuk mencapai sasaran, tujuan, misi dan visi organisasi yang tercantum dalam rumusan rencana strategis (strategic planning) perusahaan. Kinerja merupakan prestasi yang diraih oleh entity pada satu periode tertentu, memberikan gambaran bahwa prestasi tersebut merupakan efektivitas operasional suatu entity serta dapat terlihat dari sisi keuangan dan juga dari sudut pandang manajemen.

Meskipun demikian, untuk terbentuknya definisi agar memenuhi suatu kaedah penelitian yang dapat diukur maka dibuat suatu definisi. Apabila dibuat suatu rumusan definisi kinerja wirausaha untuk penelitian ini adalah pencapaian tujuan usaha dalam suatu periode waktu tertentu untuk mendapatkan hasil yang lebih baik berbanding periode sebelumnya.

\section{Kinerja Keuangan}

Umumnya kinerja keuangan dijadikan sebagai dasar untuk mengukur sehat atau tidaknya suatu perusahaan. Kinerja keuangan perusahaan digunakan sebagai media pengukuran subjektif yang menggambarkan efektivitas penggunaan aset oleh suatu perusahaan dalam mengelola bisnisnya dalam meningkatkan pendapatan. Menurut (Gakure, Memba, \& Karanja, 2012) bahwa indikator kinerja keuangan suatu UKM di antaranya berupa penjualan per tahun, profit per tahun, aset bersih yang dimiliki serta jumlah karyawan.

Merujuk kepada Kamus Besar Bahasa Indonesia (KBBI, 2001) kinerja keuangan adalah sesuatu yang dicapai atau prestasi yang diperlihatkan. Menurut Widodo dkk. (2003) ukuran untuk menentukan kinerja usaha mikro menggunakan indikator-indikator kinerja berupa jumlah penjualan, laba, harta kekayaan usaha, nilai aset keluarga, kredit, total biaya untuk keluarga, serta jumlah tabungan yang dimiliki keluarga. 
Bagi Umar (2006) kinerja ekonomis memberikan penekanan terhadap seberapa besar entitas organisasi mampu menghasilkan keuntungan yang telah direncanakan untuk tercapainya visi dan misi organisas. Kinerja keuangan merupakan pencapaian atau prestasi yang telah diraih oleh manajemen perusahaan dalam menjalankan fungsinya mengelola aset perusahaan secara efektif selama periode tertentu (Rudianto, 2013).

Menurut Venkatraman dan Ramanujam (1986) kinerja keuangan merupakan salah satu indikator yang dapat menggambarkan kinerja usaha misalnya kinerja peningkatan penjualan, kemampuan menghasilkan keuntungan, dan lain-lain. Fahmi (2011) berpendapat bahwa kinerja keuangan adalah suatu analisis yang dijalankan untuk mengamati apakah suatu perusahaan telah menjalankan dan menggunakan pedoman pelaksanaan keuangan secara baik dan benar.

Penulis membuat suatu kesimpulan bahwa kinerja keuangan adalah usaha yang dilakukan oleh perusahaan untuk dapat menilai keberhasilan perusahaan dalam memperoleh laba, sehingga dapat memberikan gambaran tentang prospek, pertumbuhan, dan juga potensi perkembangan perusahaan dengan memanfaatkan sumber daya yang dimiliki, serta mencapai keberhasilan jika telah memenuhi standar dan tujuan yang telah ditetapkan sebelumnya.

\section{Pentingnya Kinerja Keuangan}

Menurut Munawir (2010) penilaian kinerja keuangan perusahaan sangat penting, yaitu sebagai berikut:

1. Penting untuk mengetahui tingkat likuiditas perusahaan, adalah kemampuan perusahaan untuk memperoleh kewajiban keuangan yang harus dipenuhi atau kemampuan perusahaan untuk memenuhi kewajiban keuangan pada saat diperlukan.

2. Sebagai alat untuk mengetahui tingkat solvabilitas, adalah kemampuan perusahaan untuk memenuhi kewajiban keuangannya apabila perusahaan tersebut dilikuidasi yang terdiri dari kewajiban keuangan jangka pendek maupun kewajiban keuangan jangka panjang.

3. Sebagai alat untuk mengetahui tingkat rentabilitas atau profitabilitas, yang memberikan gambaran kemampuan perusahaan dalam menghasilkan laba selama periode tertentu.

4. Penting untuk mengetahui tingkat stabilitas usaha, yaitu berupa kemampuan perusahaan untuk melakukan usahanya dengan stabil, diukur dengan memperhatikan kemampuan perusahaan untuk membayar kewajiban atas beban bunga atas hutang termasuk membayar kembali pokok pinjamannya tepat waktu serta kemampuan membayar deviden secara teratur kepada para pemegang saham atau pemodal tanpa mengalami hambatan keuangan.

Sementara itu Jumingan (2011) menyatakan bahwa kinerja keuangan memiliki beberapa tujuan penting, di antaranya adalah:

1. Untuk mengetahui berhasil atau tidaknya pengelolaan keuangan perusahaan terutama kondisi likuiditas, ketersediaan modal, maupun profitabilitas.

2. Untuk mengetahui kemampuan perusahaan dalam memanfaatkansemua aset yang ada dalam upaya mencapai laba secara efisien.

\section{Pengukuran Kinerja Keuangan UMKM}

Ali (2003) berpendapat bahwa kinerja UMKM dapat dianalisis dengan menggunakan pendekatan berdasarkan kepada tiga asumsi yaitu sebagai berikut;

a. Terdapat berbagai kesulitan dalam melakukan pengukuran kinerja UMKM secara kuantitatif, hal ini sebabkan karena keterbatasan sumber daya (terhadap pemahaman keuangan dan tenaga kerja).

b. Pada umumnya pengukuran kinerja melihat indikator keuangan yang kompleks, hal ini berakibat tidak secara lengkapnya menggambarkan kondisi aktual yang terjadi pada bisnis yang dijalankan.

c. Umumnya pengukuran kinerja yang kerap digunaka relatif hanya sesuai apabila digunakan untuk perusahaan skala besar yang mempunyai struktur lengkap dalam manajemen perusahaan. 
Lebih lanjut Aribawa (2016) membuat rumusan pendekatan non-cost performance measures untuk mengukur kinerja UMKM sebagai pengukuran kinerja keuangan dan non keuangan. Pengukuran yang digunakan lebih mudah (karena melalui persepsi) maka diharapkan dapat memberikan gambaran kondisi sebenarnya pada UMKM tersebut, serta ke depan perlu dilakukan edukasi untuk menilai kinerja perusahaan dengan menggunakan indikator yang mudah seperti; pertumbuhan usaha, company's total revenue (sales), total orders dan posisi kas.

Alat yang dapat digunakan untuk mengukur kinerja keuangan UMKM salah satunya yaitu dengan menggunakan teknik analisis rasio keuangan. Analisis rasio keuangan merupakan salah satu alat analisis keuangan untuk menilai kondisi keuangan dan kinerja usaha serta memberikan gambaran baik atau buruknya kondisi atau posisi keuangan usaha kepada pihak penganalisa (Sujarweni, 2017).

Hery (2016) mengemukakan bahwa dengan membandingkan rasio keuangan dari tahun ke tahun, maka seorang analis bisa mengetahui komposisi perubahaan yang terjadi dan menentukan apakah ada peningkatan atau penurunan posisi keuangan dan kinerja perusahaan selama periode tersebut.

Kinerja keuangan suatu UMK dapat dilihat dan diukur salah satunya adalah dengan cara melakukan analisis terhadap laporan keuangan yang tersedia. Dengan demikian, kondisi perkembangan keuangan perusahaan dapat diketahui, baik pada periode yang telah lalu maupun untuk periode yang selanjutnya. Kinerja keuangan berkaitan sangat erat dengan pengelolaan keuangan dan hasil operasi bisnis perusahaan. Ketidakpastian masa akan datang dapat diprediksi dengan menilai kinerja keuangan dan sebagai alat untuk membantu dalam mengambil keputusan keuangan, juga dapat mengetahui prestasi kerjanya sendiri sehingga dapat dilakukan tindak perbaikan atas kelemahan atau untuk meningkatkan produktifitasnya. Terdapat banyak faktor yang berpengaruh terhadap kinerja perusahaan, di antaranya dengan melakukan pertimbangan penilaian kinerja adalah penentuan sasaran dan tanggungjawab yang dibebankan kepada setiap bagian yang ada dalam perusahaan.

Analisis kinerja keuangan dapat dilakukan analisis kinerja keuangan dengan cara menganalisis rasio keuangan. Rasio keuangan merupakan suatu kajian yang melihat perbandingan antara jumlah-jumlah yang terdapat pada laporan keuangan ini sangat penting untuk melakukan analisis terhadap posisi keuangan perusahaan. Menurut Kasmir (2013) rasio keuangan adalah serangkaian aktifitas membandingkan angka-angka yang tercantum dalam laporan keuangan dengan cara membandingkan satu angka dengan angka lainnya. Perbandingan ini dapat dilakukan antara satu komponen dengan komponen lainnya dalam satu laporan keuangan.

Sementara itu menurut Jumingan (2009), rasio keuangan merupakan angka yang mengambarkan hubungan antara suatu unsur dengan unsur lainnya dalam laporan keuangan. Hubungan antara unsur-unsur laporan keuangan tersebut disajikan dalam bentuk yang sistematis dan sederhana. Rasio keuangan adalah alat ukur yang digunakan dalam menilai kinerja dan keadaan keuangan perusahaan. Rasio keuangan juga merupakan perbandingan antara satu atau lebih akun laporan dimana tujuannya adalah untuk menilai kemampuan perusahaan dalam mengelola usahanya.

Menurut Samryn (2012) terdapat beberapa faktor-faktor yang mempengaruhi rasio keuangan di antaranya adalah:

a. Penyebab kelemahan analisis rasio keuangan berhubungan dengan identifikasi bidang usaha bagi perusahaan yang akan dianalisis.

b. Rasio keuangan berhubungan naik turunnya kegiatan bisnis yang musiman.

Kasmir (2012) mengutip J. Fred Weston terdapat beberapa jenis rasio keuangan yaitu sebagai berikut:

1. Rasio likuiditas

2. Rasio solvabilitas

3. Rasio aktivitas

4. Rasio profitabilitas 
5. Rasio pertumbuhan

6. Rasio penilaian.

Dimana semua rasio tersebut mempunyai fungsi masing-masing yang berguna untuk menunjukkan seberapa baik atau buruknya kinerja keuangan sebuah perusahaan.

\section{METODE PENELITIAN}

Penelitian ini adalah studi literatur dengan jenis penelitian library research, karena dalam mengumpulkan, analisis, serta mengolah data-data dalam artikel ini bersumber dari studi literatur yang tertulis dan dianggap relevan dalam mengumpulkan data yang fokus pada kajian artikel mengenai penilaian kinerja keuangan UMK. Data yang digunakan adalah data sekunder berupa data-data yang merujuk kepada informasi yang berasal dari berbagai sumber yang tersedia, baik berupa catatan, publikasi terbitan pemerintah, analisis oleh media massa, sumber internet dan sumber-sumber lainnya. Data-data yang diperoleh kemudian dipaparkan secara deskriptif dan kemudian ditarik suatu kesimpulan.

\section{HASIL DAN PEMBAHASAN}

Dalam melihat kinerja keuangan UMK dapat diukur berdasarkan jumlah aset, omset atau volume penjualan dan laba yang diperoleh dalam periode tertentu. Aset adalah harta/kekayaan (sumberdaya) yang dimiliki oleh business entity yang dapat diukur secara jelas dengan menggunakan satuan uang serta sistem urutannya berdasar kepada seberapa cepat pertumbuhannya dikonversi menjadi satuan uang kas. Memberikan manfaat baik secara langsung ataupun tak langsung, bersifat produktif dan dikategorikan sebagai bagian operasi perusahaan dan mempunyai kemampuan dalam mengurangi pengeluaran uang kas. Memiliki potensi manfaat di masa yang akan datang, potensi manfaat tersebut bisa dalam bentuk hal-hal produktif yang bisa menghasilkan kas atau setara kas.

Aset juga mempunyai manfaat lain yaitu sebagai penghasil barang dan jasa, dapat ditukar dengan aktiva lain, dan dapat digunkan untuk melunasi kewajiban (hutang). Sementara itu omset penjualan berupa volume penjualan. Omset penjualan akan meningkat apabila diikuti dengan kegiatan penjualan yang efektif. Omset dapat diartikan sebagai jumlah, sedangkan penjualan dapat diartikan sebagai aktivitas menjual barang atau jasa dengan tujuan mencari keuntungan. Sedangkan omset penjualan adalah jumlah total penjualan barang atau jasa dalam periode tertentu, ditentukan berdasarkan sejumlah nilai uang yang dikumpulkan. Serta laba bersih adalah kelebihan jumlah pendapatan yang dibandingkan dengan total beban atau biayanya. Terkadang dikenal juga dengan istilah pendapatan bersih.

Berbagai informasi yang dihasilkan oleh akuntansi sehubungan dengan kinerja keuangan berguna bagi UMK, yaitu berupa:

1. Sebagai dasar pertimbangan dalam melakukan pembelian bahan baku untuk produksi dan alat-alat produksi yang akan digunakan ataupun jasa.

2. Sebagai salah satu dasar dalam menyusun rencana masa depan.

3. Membuat keputusan sehubungan dengan penetapan harga

4. Berguna untuk pengajuan permohonan pembiayaan pada bank atau lembaga pembiayaan non-bank

5. Sangat berguna untuk pengembangan usaha

6. Sebagai peningkatan dan pengembangan sumberdaya manusia.

7. Menciptakan lapangan pekerjaan.

8. Dapat meningkatkan penghasilan karyawan.

9. Sebagai penambahan aset usaha.

Sumber informasi yang terdapat dari akuntansi bisa digunakan untuk menilai kinerja usaha yang diukur melalui profitabilitas, daya saing serta pertumbuhan dan perkembangan usaha. Sedangkan akuntansi merupakan indikator utama kinerja setiap usaha karena informasi yang disediakan oleh catatan-catatan akuntansi berguna dalam pengambilan keputusan. Oleh karena 
itu akuntansi dapat dijadikan sebagai suatu alat untuk meningkatkan kinerja usaha khususnya kinerja keuangan. Kinerja keuangan memberikan banyak manfaat jika pengusaha UMK melakukannya. Berbagai kesempatan akan hadir jika dilakukan kinerja keuangan dianggap baik oleh stake holders.

\section{KESIMPULAN}

Berbagai informasi yang dihasilkan oleh akuntansi sehubungan dengan kinerja keuangan berguna bagi UMK, yaitu sebagai berikut; sebagai dasar pertimbangan dalam melakukan pembelian bahan baku untuk produksi dan alat-alat produksi yang akan digunakan ataupun jasa, sebagai salah satu dasar dalam menyusun rencana masa depan, membuat keputusan sehubungan dengan penetapan harga, berguna untuk pengajuan permohonan pembiayaan pada bank atau lembaga pembiayaan non-bank, berguna untuk pengembangan usaha, sebagai peningkatan dan pengembangan sumberdaya manusia, menciptakan lapangan pekerjaan, dapat meningkatkan penghasilan karyawan, dan sebagai penambahan aset usaha.

\section{DAFTAR PUSTAKA}

Aminul Islam, M., Aktaruzzaman Khan, M., Obaidullah, A. Z. M., \& Syed Alam, M. (2011). Effect of Entrepreneur and Firm Characteristics on the Business Success of Small and Medium Enterprises (SMEs) in Bangladesh. International Journal of Business and Management, 6(3). https://doi.org/10.5539/ijbm.v6n3p289.

Ali, I. 2003. A Performance Measurement Framework for a Small and Medium Enterprise. Univerity of Alberta Dissertation.

Aribawa, D. (2016). Pengaruh Literasi Keuangan Terhadap Kinerja dan Keberlangsungan UMKM Di Jawa Tengah. Siasat Bisnis, 20(1), 1-13. https://doi.org/10.1007/s10006-0130431-4

BPS. (2018). Potensi Usaba Mikro Kecil.

Dhaliwal, S. (2000). Entrepreneurship - a learning process: The experiences of Asian female entrepreneurs and women in business. Education + Training, 42(8), 445-453. https://doi.org/10.1108/00400910010379970

Gakure, Memba, \& Karanja. (2012). V enture C apital ( V C ): Its Impact on G rowth of Small and M edium E nterprises in K enya. International Journal of Business and Social Science, 3(6), 3238.

Jumingan, (2009), Analisis Laporan Keuangan. Cetakan ketiga. PT.Bumi Aksara. Jakarta.

Kasmir..(2013). Analisis Laporan Keuangan. PT Raja Grafindo Persada. Jakarta

Laitinen, E. K. (2002). A dynamic performance measurement system: Evidence from small Finnish technology companies. Scandinavian Journal of Management, 18(1), 65-99. https://doi.org/10.1016/S0956-5221(00)00021-X

Masuo, D., Fong, G., Yanagida, J., \& Cabal, C. (2001). Factors Associated with business and family success: A comparison of single manager and dual manager family business households. Journal of Family and Economic Issues, 22(1), 55-73. https://doi.org/10.1023/A:1009492604067

Nneka, A. A. (2015). Factors that affect the performance of women entrepreneurs in the micro scale enterprises in Southwestern Nigeria. The Business \& Management Review, 6(2), 30-31. Retrieved from https://search.proquest.com/openview/d59294661acefe068c0d933fe6f39955/1?pqorigsite $=$ gscholar\&cbl $=2026610$

O’Regan, N., Sims, M., \& Ghobadian, A. (2005). High performance: Ownership and decisionmaking in SMEs. Management Decision, 43(3), 382-396. https://doi.org/10.1108/00251740510589760 
Paige, R. C., \& Littrell, M. A. (2002). Craft Retailers' Criteria for Success and Associated Business Strategies. Journal of Small Business Management, 40(4), 314-331. https://doi.org/10.1111/1540-627x.00060

Reijonen, H., \& Komppula, R. (2007). Perception of success and its effect on small firm performance. Journal of Small Business and Enterprise Development, 14(4), 689-701. https://doi.org/10.1108/14626000710832776

Sahabuddin, R. (2015). MENINGKATKAN KINERJA USAHA Mikro, Kecil, \& Menengah Dalam Persprektif Kewirausabaan).

Samryn, L. M.,SE.,AK.,MM (2011). Pengantar Akuntansi Mudah membuat Jurnal Dengan Pendekatan Siklus Transaksi. PT Raja Grafindo Persada. Jakarta

Sujarweni, V. Wiratna 2017, Analisis Laporan Keuangan Teori,Aplikasi danHasil Penelitian, Pustaka Baru Press, Yogyakarta.

UU No. 20 Tahun 2008. UU No. 20 Tahun 2008. , UU No. 20 Tahun 2008 \ (2008).

Venkatraman, N., \& Ramanujam, V. (1986). Measurement of Business Performance in Strategy Research: A Comparison of Approaches. Academy of Management Review, 11(4), 801-814. https://doi.org/10.5465/amr.1986.4283976

Welter. (2012). Women's entrepreneurship and economics: New perspectives, practices, and policies. In Women's Entrepreneurship and Economics: New Perspectives, Practices, and Policies (pp. 73-88). https://doi.org/10.1007/978-1-4614-1293-9

Winbaktianur, D. Harding, Hinduan Z.R, K. A. . (2020). Penilaian kinerja usaha mikro dan kecil, perlukah? Biopsikososial, 4(1), 240-262. 